\title{
norden
}

Nordsyn - ecodesign and energy labelling requirements for electric heat pumps and electric boilers

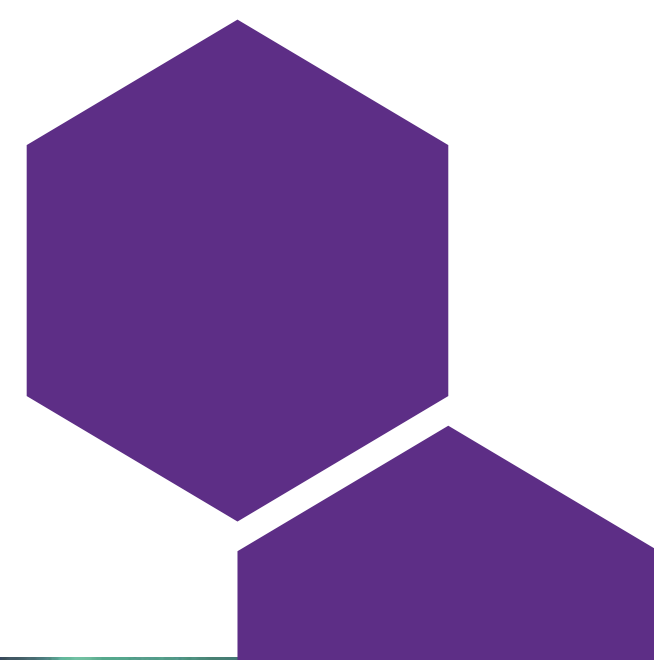

W. wh 
Nordsyn - ecodesign and energy labelling requirements for electric heat pumps and electric boilers

ISBN 978-92-893-4372-5 (PRINT)

ISBN 978-92-893-4373-2 (PDF)

http://dx.doi.org/10.6027/ANP2015-784

ANP 2015:784

(c) Nordic Council of Ministers 2015

Layout: Erling Lynder

Cover photo: Ragnar Th. Sigurdsson/ARCTIC IMAGES

Photos: Signelements

The quality of the tables in this publication is slightly distorted, but based on the best available materials.

This publication has been published with financial support by the Nordic Council of Ministers. However, the contents of this publication do not necessarily reflect the views, policies or recommendations of the Nordic Council of Ministers.

www.norden.org/nordpub
Nordic co-operation

Nordic co-operation is one of the world's most extensive forms of regional collaboration, involving Denmark, Finland, Iceland, Norway, Sweden, and the Faroe Islands, Greenland, and Åland.

Nordic co-operation has firm traditions in politics, the economy, and culture. It plays an important role in European and international collaboration, and aims at creating a strong Nordic community in a strong Europe.

Nordic co-operation seeks to safeguard Nordic and regional interests and principles in the global community. Common Nordic values help the region solidify its position as one of the world's most innovative and competitive.

Nordic Council of Ministers

Ved Stranden 18

DK-1061 Copenhagen K

Phone (+45) 33960200

www.norden.org 


\section{Nordsyn - ecodesign and energy labelling requirements for electric heat pumps and electric boilers}

Preface $\quad 4$

$\begin{array}{ll}\text { Summary } & 6\end{array}$

Which products must comply with the requirements? $\quad 8$

What are the requirements for energy labelling? $\quad 11$

What are the requirements for ecodesign? 17

What are the requirements for documentation? $\quad 20$

Where can I find information? $\quad 22$ 


\section{Preface}

The European Commission published four regulations concerning ecodesign and energy labelling requirements of appliances for space heating and water heating (Regulations: 811/2013, 812/2013, $813 / 2013$ and $814 / 2013$ ) in the Official Journal 6th of September 2013. The first requirements will apply from 26 September 2015.

In January 2015, the Commission published a guideline on these regulations that contains a section with frequently asked questions (FAQ). Only the regulations are legally binding - the guideline itself is not. However, it is helpful for better understanding the regulations. It is available here: https://ec.europa.eu/energy/ sites/ener/files/documents/ GuidelinesSpaceWaterHeaters_ FINAL.pdf

The Nordic market surveillance authorities have issued a series of fact sheets/guides to help manufacturers and importers of appliances prepare for the new requirements. Four of these fact sheets have been developed by Nordsyn, which is a Nordic cooperation aiming for more efficient market surveillance of ecodesign and energy labelling. Nordsyn's partners are the Swedish Energy Agency/ Energimyndigheten, the Danish Energy Agency/Energistyrelsen, the Finnish Safety and Chemicals Agency/Tukes, the Norwegian Water Resources and Energy Directorate/Norges vassdragsog Energidirektorat, and the Iceland Construction Authority/ Mannvirkjastofnun.

\section{- "Fact sheet on ecodesign and} energy labelling requirements for electric heat pumps and electric boilers".

- "Fact sheet on ecodesign and energy labelling requirements for electric heat pump water heaters and electric conventional water heaters".

- "Fact sheet on ecodesign and energy labelling requirements for hot water storage tanks".

- "Fact sheet on energy labelling requirements for packages of water heaters and solar devices".
The Norwegian Water Resources and Energy Directorate (NVE) has also developed two additional fact sheets:

- "Fact sheet on ecodesign and energy labelling requirements for oil- and gas-fired boilers".

- "Fact sheet on energy labelling requirements for packages of space heaters/combination heaters, temperature controls and solar devices".

Together, these fact sheets cover the most common space and water heating appliances on the Nordic market. However, some appliances are not covered by these regulations, e.g. micro CHP appliances and gas-fired water heaters. The individual fact sheets refer to one another when relevant and it is therefore recommended to have them all in order to gain their full benefit.

The fact sheets summarise the contents of the Regulations and are addressed to manufacturers, importers and other interested parties. The fact sheets are not 
legally binding and they do not substitute the Regulations and, in the event of doubt, the Regulations are applicable (any binding interpretation can only be made by the EU court). The fact sheets have been developed by Viegand Maagøe A/S, Denmark, as part of
Nordsyn and of the Nordic Prime

Ministers' overall green growth

initiative: The Nordic Region -

leading in green growth under the

Nordic Council of Ministers - read more at www.nordicway.org or at www.norden.org/greengrowth

October 2015

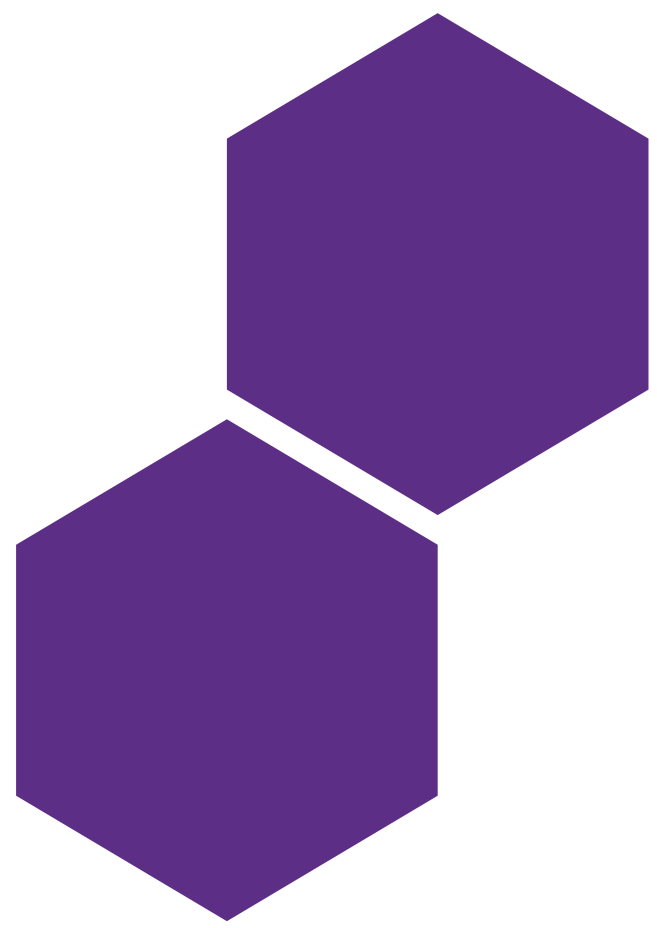




\section{Summary}

\section{Are you a manufacturer or importer of electric heat pumps or electric boilers?}

Please be aware that there are requirements for energy efficiency and energy labelling of heat pumps and electric boilers. Heat pumps and electric boilers for water based central heating systems must meet the ecodesign requirements. This means that the product is designed to meet, for example, the minimum energy efficiency requirements and the maximum permissible sound power level.

Heat pumps and electric boilers must also be energy labelled.

\section{Which products?}

The Ecodesign Regulation applies to:

- Heat pumps and electric boilers for space heating with a rated output up to and including $400 \mathrm{~kW}$.

- Heat pumps and electric boilers for combined space and water heating with a rated output up to and including $400 \mathrm{~kW}$.
The Energy Labelling Regulation applies to:

- Heat pumps and electric boilers for space heating with a rated output up to and including $70 \mathrm{~kW}$.

- Heat pumps and electric boilers for combined space and water heating with a rated output up to and including $70 \mathrm{~kW}$.

\section{When?}

The requirements for energy labelling and ecodesign both apply from the 26 September 2015.

The ecodesign regulations for heat pumps and electric boilers applicable from 26 September 2015 introduce requirements for:

- Seasonal space heating energy efficiency for heat pumps with a rated output up to and including $400 \mathrm{~kW}$. These requirements will be tightened from 26 September 2017.

- Water heating energy efficiency for heat pumps for combined space and water heating with a rated output up to and including $400 \mathrm{~kW}$. These requirements will be tightened from 26 September 2017.

- Maximum permissible sound power levels.

- Information on the properties of heat pumps and electric boilers for space heating and combined space and water heating.

The energy labelling regulations for heat pumps and electric boilers applicable from 26 September 2015 introduce requirements for:

- The provision of a printed EU energy label and a product fiche.

- Information on the product's energy class in advertisements and technical promotion material.

- The provision of electronic versions of the EU energy label and product fiche to dealers for products placed on the market with a new model identifier.

- The display of the energy label and product fiche when the products are offered for sale through the internet. 


\section{Who?}

You are responsible for ensuring and documenting compliance with the requirements if you are:

- A manufacturer in the EEA producing heat pumps or electric boilers to be placed on the market in the EEA.

- An importer of heat pumps or electric boilers from a country outside the EEA to be placed on the market in the EEA.

- An authorised representative in the EEA for a manufacturer that is situated in a country outside the EEA.

The responsible parties mentioned above are hereinafter referred to as suppliers.

Dealers of space heaters are responsible for ensuring that the energy label provided by the supplier is clearly visible on each space heater at the point of sale. Suppliers, dealers and installers placing packages of heat pumps and electric boilers combined with temperature controllers and/ or solar devices on the market, and/or putting them into service, are also responsible for ensuring that a package label is produced and provided with the package of products. These requirements are described in "Fact sheet to energy labelling requirements for packages of space heaters/ combination heaters, temperature controls and solar devices".

The EEA (European Economic Area) includes the EU member states and the EFTA countries.

\begin{abstract}
Why?
Heat pumps and electric boilers account for a large share of the energy consumption in European households. Consequently, the EU has decided to reduce the energy consumption of heat pumps and electric boilers by introducing requirements for energy efficiency and by introducing energy labelling with energy classes.
\end{abstract}

\section{Where can I find more information?}

You can find the relevant regulations on the last page of this fact sheet, or read more about ecodesign and energy labelling on the webpages of your market surveillance authorities and the Commission (https://ec.europa.eu/energy/en/topics/ energy-efficient-products/heaters).

\section{Disclaimer}

This fact sheet presents the contents of the Regulations and is addressed to manufacturers, importers and other interested parties. This fact sheet is not legally binding and does not substitute the Regulations. In the event of doubt, the Regulations are applicable, and any binding interpretation can only be made by the EU court. 


\section{Which products must comply with the requirements?}

\author{
Heat pumps and electric boilers \\ From 26 September 2015, the \\ ecodesign requirements will apply \\ to heat pumps and electric boilers \\ for water based central heating \\ systems with a rated output \\ $\leq 400 \mathrm{~kW}$, including those that \\ are part of a package together \\ with temperature control and/or \\ solar device.
}

The requirements described in these fact sheets do not apply to:

- Heat pumps and electric boilers specifically designed for production of hot water. Such heat pumps and electric boilers are covered by the requirements for water heaters.

- Heat pumps and electric boilers for heating and distributing gaseous heat transfer media such as air.

- Heat pumps and electric boilers designed for heaters and heater housings to be equipped with such heat generators placed on the market before 1 January 2018 to replace identical heat generators and identical heater housings. The replacement product or its packaging must clearly indicate the heater for which it is intended.

The requirements for energy labelling of heat pumps and electric boilers only apply to heat pumps and electric boilers with a rated output $\leq 70 \mathrm{~kW}$.

\section{A distinction is made between} heat pumps and electric boilers for space heating and heat pumps and electric boilers for combined space and water heating. In addition to providing space heating, combination heat pumps and electric combination boilers must also be designed to provide hot water and to connect to an external water supply.

A distinction is also made between heat pumps and low temperature heat pumps. Low temperature heat pumps are space heating units that are specifically designed for low temperature application and that cannot supply heated water at an outlet temperature of $52^{\circ} \mathrm{C} .{ }^{1}$

Figure 1 outlines three different types of systems: a) is a heater exclusively for space heating, b) is also characterised as a space heater because it is not capable of providing domestic hot water or be connected to an external water supply, c) is a combination heater. There are separate ecodesign and energy labelling requirements for hot water storage tanks, see "Fact sheet on ecodesign and energy labelling requirements for hot water storage tanks".

Basically, space heaters and combination heaters are assumed not to be equipped with temperature controls and solar devices, and the ecodesign and energy labelling requirements are applicable to such individual heat pumps and electric boilers. However, there are also requirements for energy labelling for packages consisting of heat pumps and electric boilers combined with temperature controllers and/or solar devices. These requirements are described in the "Fact sheet on energy labelling requirements for packages

1 Applies at an inlet dry bulb temperature (inlet wet bulb temperature) of $-7{ }^{\circ} \mathrm{C}\left(-8^{\circ} \mathrm{C}\right.$, respectively) in the designed reference conditions under mean climate conditions. 
of space heaters/combination heaters, temperature controls and solar devices". In reality, many space and combination heaters (for example most ground source heat pumps), have integrated temperature control. These space and combination heaters can be labelled both as products and as packages of products.

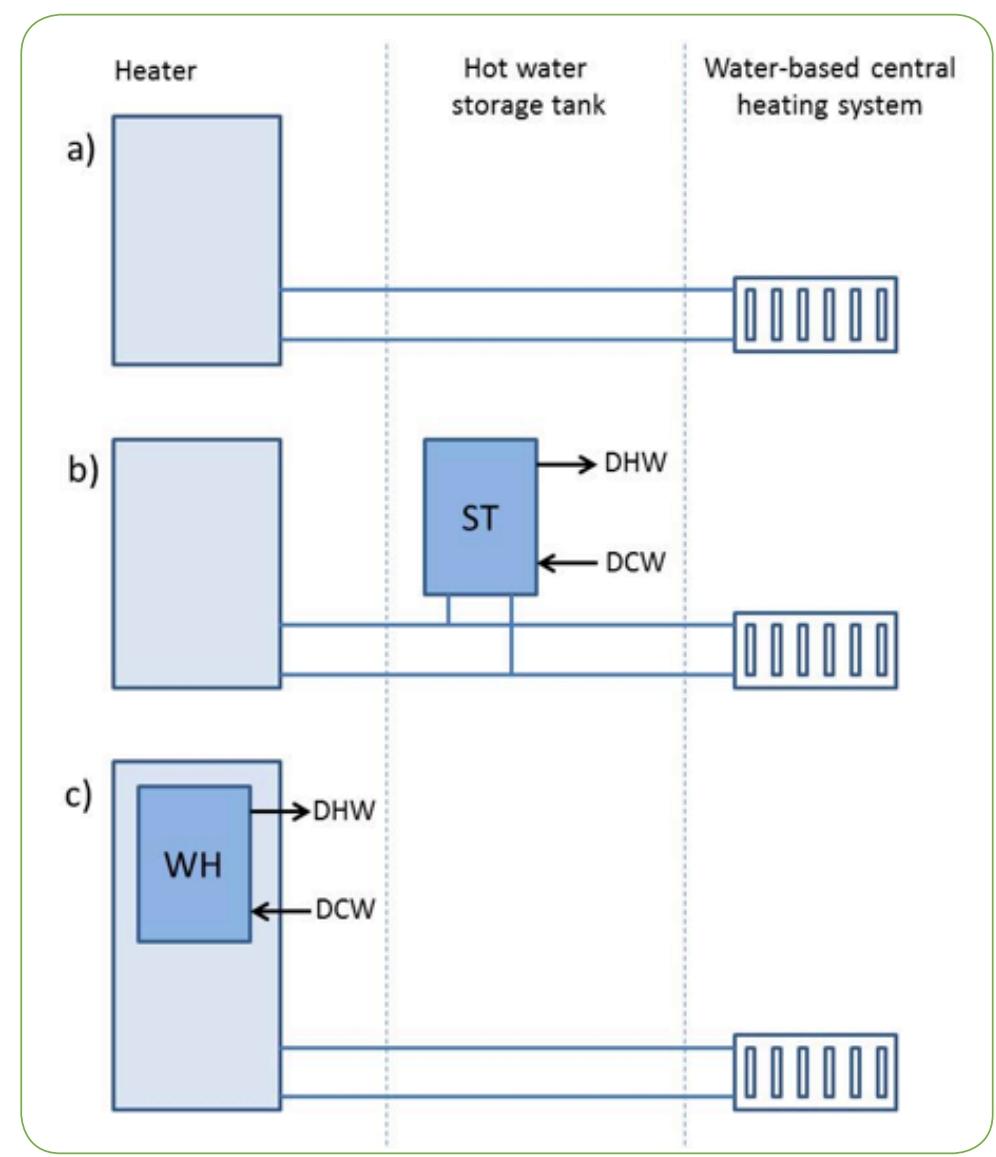

Figure 1: Different types of supply systems

The listed requirements cover the two main types of heat pumps for water based central heating systems, air-to-water heat pumps and brine-to-water/water-to-water heat pumps.

Figure 2 shows an example of an air-to-water heat pump. This heat pump is for combined space and water heating and has both an outdoor unit and an indoor unit.

Figure 3 shows an example of a brine-to-water/water-to-water heat pump. This heat pump is for combined space and water heating and the heat source is horizontally placed tubes. The heat source comes in different shapes, ground heat in terms of horizontal tubes or vertical boreholes, heat exchange with ground water, sea water, waste water, etc.

An electric boiler heats a vessel by means of an electric heater. The amount of produced heat is almost equivalent to the amount of used electricity. 


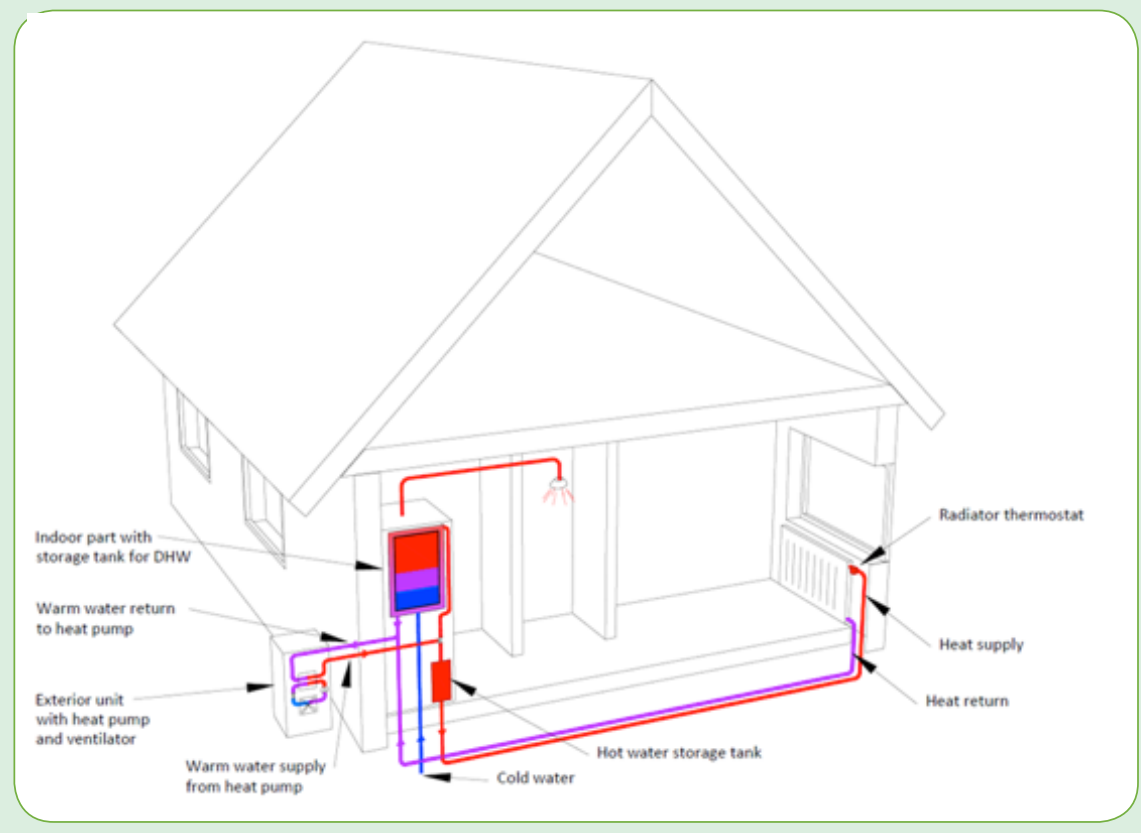

Figure 2: Air-towater heat pump for combined space and water heating with an outdoor unit and an indoor unit

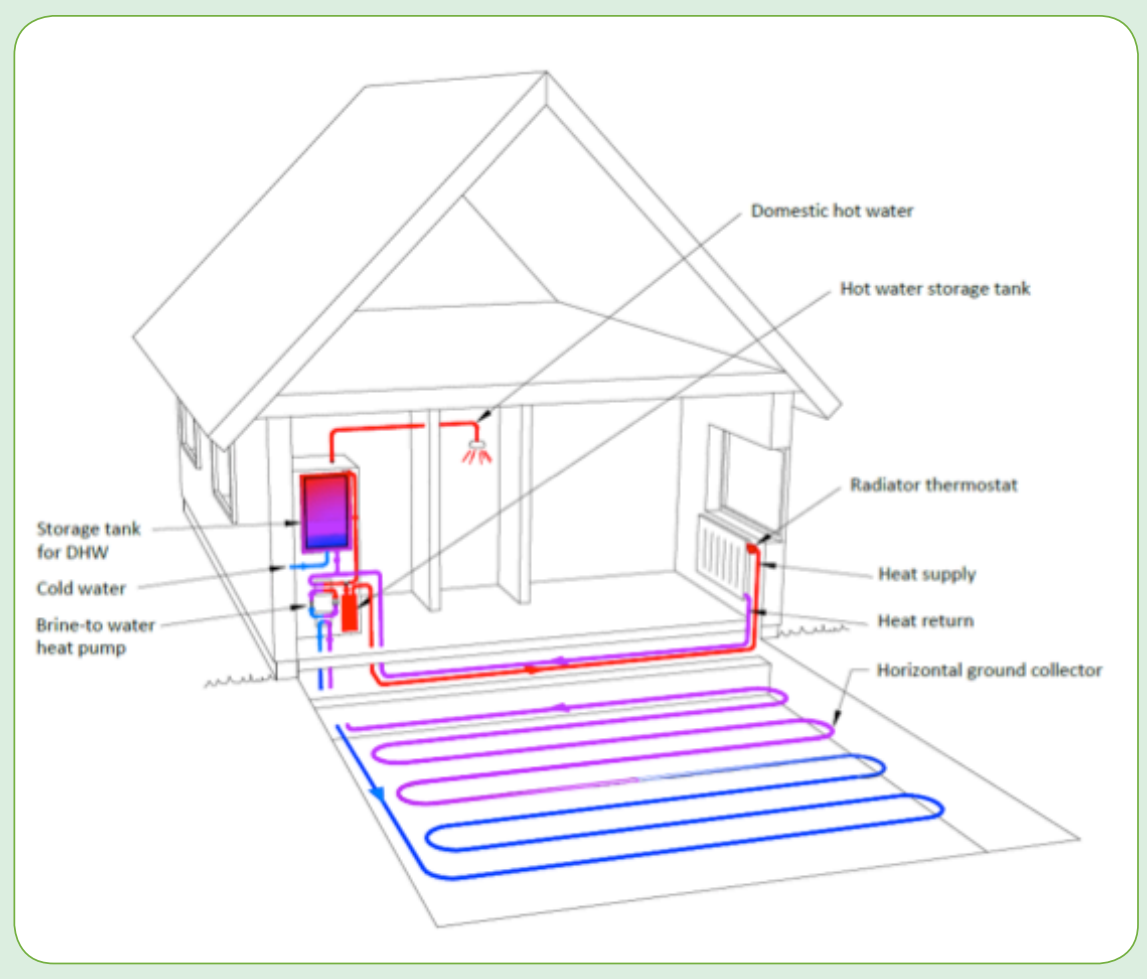

Figure 3: Brine-towater/water-to-water heat pump for combined space and water heating. The heat source consists of horizontal tubes 


\section{What are the requirements for energy labelling?}

From 26 September 2015, heat pumps and electric boilers must be labelled with the EU energy label. The label is identical in all the EU/EEA countries and includes pictograms instead of text, so that the label can be easily understood in all the countries.

The label has the recognisable red and green arrows, and the $A-G$ scale is expanded with the energy classes $A^{+}, A^{++}$and $A^{+++}$.

The supplier is responsible for providing a printed energy label together with each heat pump or electric boiler.

\section{Energy efficiency classes on the label}

The label for electric boilers for space heating includes a single scale and the energy classes will be introduced in two stages according to the schedule in Table 1. From 26 September 2015 an energy label with energy classes from $A^{++}$to $G$ is required, and from 26 September 2019 a label with energy classes from $A^{+++}$to $D$ is required.
The label for heat pumps for space heating includes two scales, one scale for medium-temperature application (inlet temperature to the heater at $55^{\circ} \mathrm{C}$ ) and one scale for low temperature application (inlet temperature to the heater at $35^{\circ} \mathrm{C}$ ). The label for low temperature heat pumps is different in that it includes one single scale and a specification for low temperature application. The energy classes and the schedule are the same as for electric boilers, see Table 1 .

The label for combination heaters includes two scales, one scale for space heating efficiency and one scale for water heating efficiency. The energy classes for the two scales are different from each other, as shown in Table 1. From 26 September 2015 an energy label with energy classes from
A to $\mathrm{G}$ is required for water heating, and from 26 September 2019 a label with energy classes from $A^{+}$to $F$ apply is required.

\section{Determination of the energy classes}

The label for space heating is based on the seasonal space heating energy efficiency $\left(\eta_{s}\right)$, which is an expression for the delivered heat in relation to the energy input during the heating season. The seasonal space heating energy efficiency is based on an average European climate similar to the climate of Strasbourg.

For heat pumps, the seasonal space heating energy efficiency is calculated based on SCOP divided by the conversion coefficient $C C$ and corrected for contributions for temperature control and electricity consumption to external pumps.

Table 1: Plan for the introduction of energy classes

\begin{tabular}{lll}
\hline Function & Energy classes & Energy label from \\
\hline Space heating & $\mathrm{A}^{++}-\mathrm{G}$ & 26 September 2015 \\
Space heating & $\mathrm{A}^{+++}-\mathrm{D}$ & 26 September 2019 \\
Water heating & $\mathrm{A}-\mathrm{G}$ & 26 September 2015 \\
Water heating & $\mathrm{A}^{+}-\mathrm{F}$ & 26 September 2019 \\
\hline
\end{tabular}


SCOP is an expression of a unit's reference annual space heating efficiency under average climate conditions.

For electric boilers, the seasonal space heating energy efficiency in active mode $\left(\eta_{\text {son }}\right)$ is divided by the conversion coefficient $C C$ and corrected for contributions for temperature control and supplementary electricity consumption and heat losses at standby mode.

The conversion coefficient $C C=2.5$ reflects the power production's estimated average efficiency of $40 \%$ in the EU.

The energy label for water heating is based on water heating energy efficiency $\left(\eta_{w H}\right)$, which is an expression of the supplied hot water in relation to the energy input for a given consumption load profile.
The load profiles are adjusted to various water consumption needs and are described by size categories ranging from XS to XXL. The load profiles are described by a number of "water draw-offs" and the requirements for water temperature and flow are spread over a day from 7:00 a.m. to 10:00 p.m. with defined intervals.

Water heating energy efficiency is calculated on the basis of tests at a load profile that fits the unit's hot water production capacity.

Methods of measurement and calculation of the various factors are described in Regulation EU No 811/2013, Annex VII. Harmonised methods will be published in the second half of 2015 at the earliest. Until then, measurements and calculations should be performed according to

\section{Be aware:}

The actual measurement results without addition of tolerances must be used for declaration of the energy efficiency class and other required declarable values.

the transitional methods published by the Commission.

\section{Information on the energy label}

Labels must include information on the heat pump's or electric boiler's energy class in medium climate conditions, rated output (including the rated output of a potential supplementing supply unit) in medium climate conditions, and the sound power level. For heat pumps, the rated output in cold and hot climate conditions (similar to the climate in Helsinki and Athens, respectively) must also be declared. The rated output in medium, cold and hot climate conditions must be declared for low temperature applications for low temperature heat pumps, and for both medium- and low temperature applications for other heat pumps. The label must provide a temperature map of Europe with the three guiding climate zones.

Information on the water heating energy class, load profile and ability to operate only during off-peak operation must also be declared. Off-peak operation is when the energy input is provided outside the draw-off period, i.e. between 10:00 p.m. and 7:00 a.m. 
For electric boilers: The labels to the left are for electric boilers for space heating and the labels to the right are for electric boilers for combined space and water heating. The two labels in the first row are required from stage one, i.e. 2015. The two labels on the second row are required from stage two, i.e. 2019.
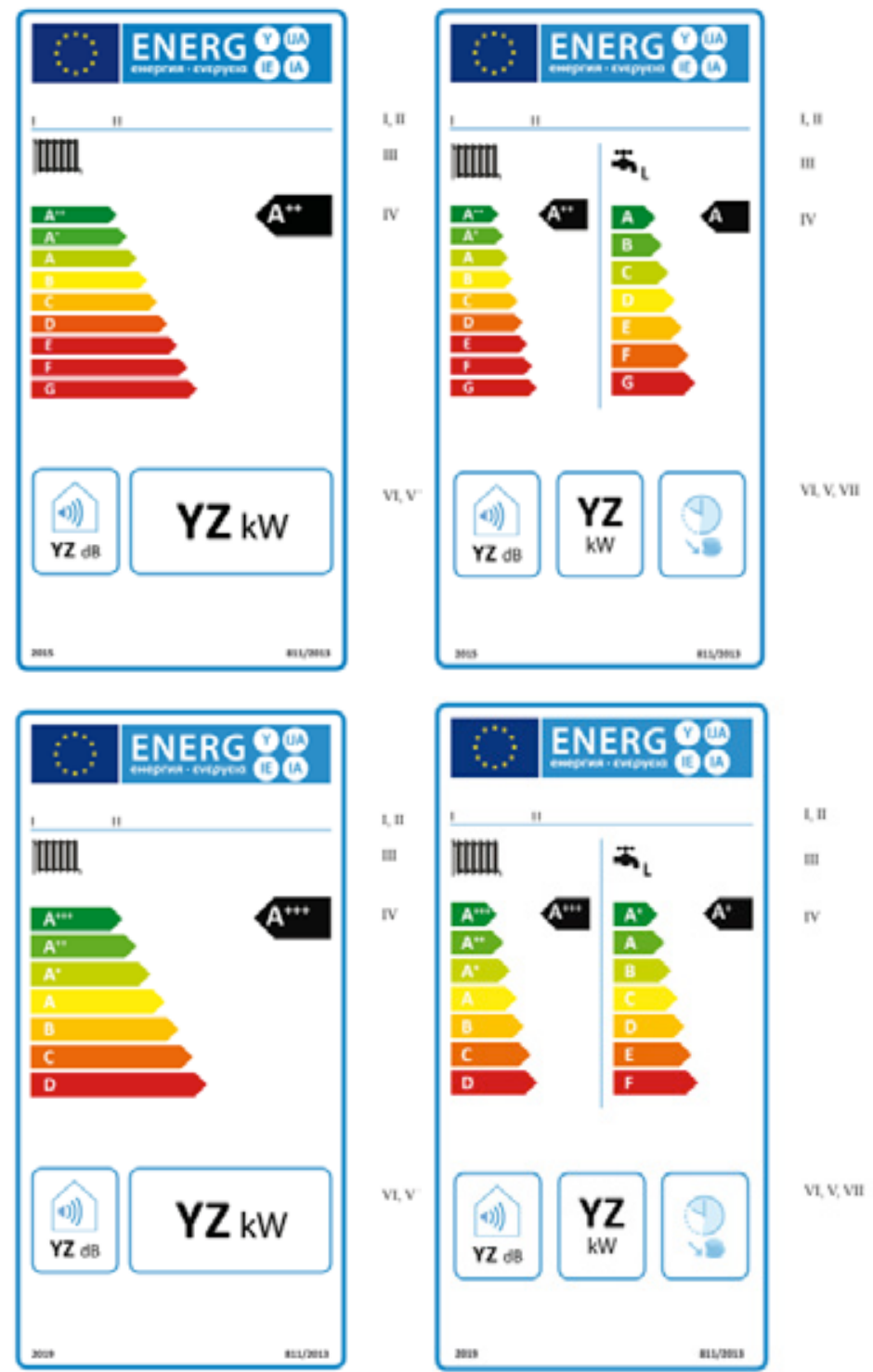
For low temperature heat pumps:

The label for low temperature heat pumps is similar to the label for electric boilers. However, a low temperature heat pump cannot be labelled as a unit for combined space and water heating. The label to the left is required from stage one, i.e. 2015. The label to the right is required from stage two, i.e. 2019.

For heat pumps: In general, the label for heat pumps for space heating shows the energy classes for medium- and low temperature application. The label to the left is required from stage one, i.e. 2015. The label to the right is required from stage two, i.e. 2019.
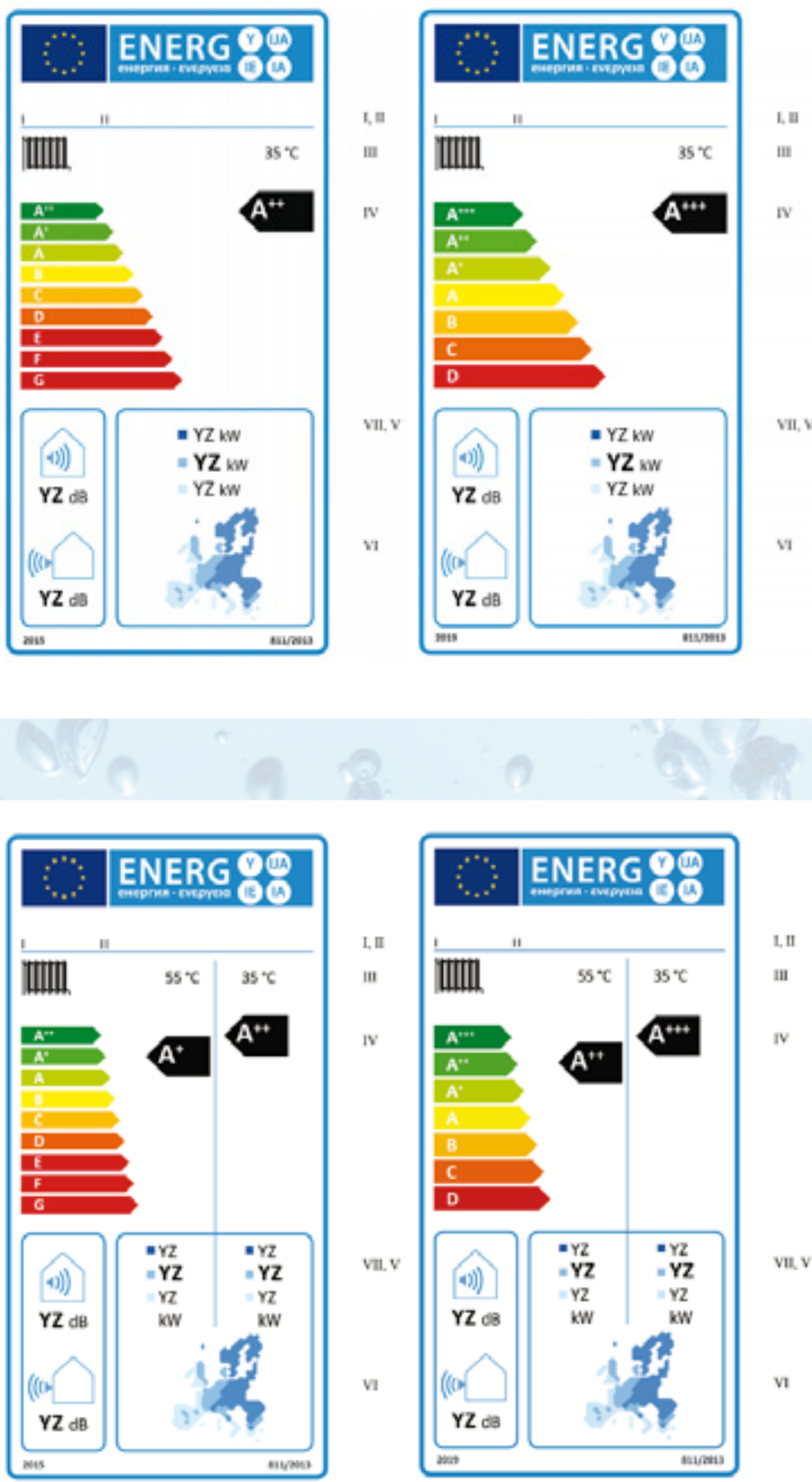
For heat pumps for combined space and water heating, note that the label for space heating is indicated in terms of medium-temperature application. The label to the left is required from stage one, i.e. 2015. The label to the right is required from stage two, i.e. 2019.

\section{Energy classes}

Table 2 describes the relationship between energy classes and seasonal space heating energy efficiency for space heating, with the exception of low temperature heat pumps and other heat pumps for space heating with low temperature application.

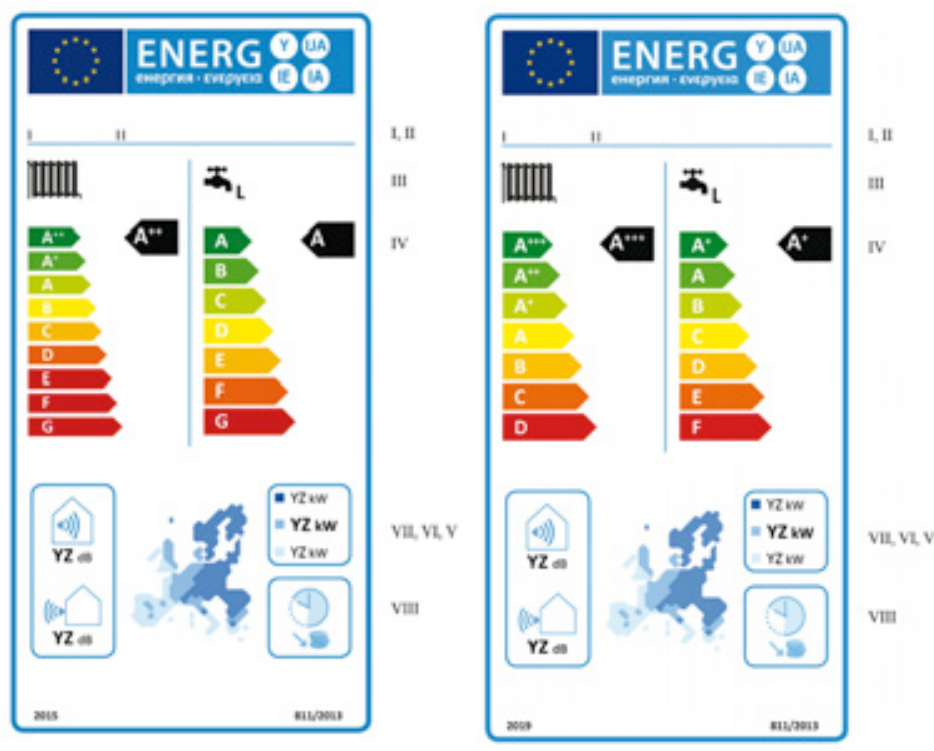

Table 2: Energy classes for space heating

\begin{tabular}{|c|c|}
\hline Seasonal space heating energy efficiency class & Seasonal space heating energy efficiency $\eta_{i}$ in $\%$ \\
\hline$A^{\cdots}$ & $\eta_{\mathrm{z}}=150$ \\
\hline$A^{*+}$ & $125 \leq \eta_{\mathrm{s}}<150$ \\
\hline$A^{*}$ & $98 \leq \eta_{3}<125$ \\
\hline A & $90 \leq \eta_{n}<98$ \\
\hline $\mathrm{B}$ & $82 \leq \eta_{s}<90$ \\
\hline c & $75 \leq \eta_{3}<82$ \\
\hline $\mathrm{D}$ & $36 \leq \eta_{3}<75$ \\
\hline E & $34 \leq \eta_{b}<36$ \\
\hline $\mathbf{F}$ & $30 \leq \eta_{3}<34$ \\
\hline G & $\eta_{t}<30$ \\
\hline
\end{tabular}


Table 3 describes the relationship between energy class and seasonal space heating energy efficiency for low temperature heat pumps and other heat pumps for space heating with low temperature application.

Table 4 describes the relationship between energy class for a given load profile and energy efficiency for water heating.
Table 3: Energy classes for low temperature heat pumps and other heat pumps for space heating with low temperature application.

\begin{tabular}{|c|c|}
\hline Seasonal tpace beating energy efficiency dass & Seasonal space heating energy efficiency $\eta_{i}$ in $\%$ \\
\hline $\mathrm{A}^{*+*}$ & $\eta_{2}=175$ \\
\hline $\mathrm{A}^{+4}$ & $150 \leq \eta_{s}<175$ \\
\hline $\mathrm{A}^{+}$ & $123 \leq \eta_{5}<150$ \\
\hline A & $115 \leq \eta_{5}<123$ \\
\hline B & $107 \leq \eta_{s}<115$ \\
\hline c & $100 \leq \eta_{s}<107$ \\
\hline D & $61 \leq \eta_{:}<100$ \\
\hline E & $59 \leq \eta_{s}<61$ \\
\hline $\mathrm{F}$ & $55 \leq \pi n_{t}<59$ \\
\hline G & $\eta_{\mathrm{g}}<55$ \\
\hline
\end{tabular}

Table 4: Energy classes for water heating

\begin{tabular}{|c|c|c|c|c|c|c|c|c|}
\hline & $3 X S$ & XXS & XS & $S$ & $\mathrm{M}$ & $\mathrm{L}$ & $\mathrm{XL}$ & $\mathrm{XXL}$ \\
\hline $\mathrm{A}^{+++}$ & $\eta_{w h} \geq 62$ & $\eta_{w h} \geq 62$ & $\eta_{w h} \geq 69$ & $\eta_{w h} \geq 90$ & $\eta_{w h} \geq 163$ & $\eta_{w h} \geq 188$ & $\eta_{w h} \geq 200$ & $\eta_{w h} \geq 213$ \\
\hline $\mathrm{A}^{++}$ & $\begin{array}{c}53 \leq \eta_{w h} \\
<62\end{array}$ & $\begin{array}{c}53 \leq \eta_{w h} \\
<62\end{array}$ & $\begin{array}{c}61 \leq \eta_{w h} \\
<69\end{array}$ & $\begin{array}{c}72 \leq \eta_{w h} \\
<90\end{array}$ & $\begin{array}{c}130 \leq \eta_{w h} \\
<16 / 3\end{array}$ & $\begin{array}{c}150 \leq \eta_{w h} \\
<188\end{array}$ & $\begin{array}{l}160 \leq \eta_{w h} \\
<200\end{array}$ & $\begin{array}{c}170 \leq \eta_{w h} \\
<213\end{array}$ \\
\hline $\mathrm{A}^{+}$ & $\begin{array}{c}44 \leq \eta_{w h} \\
<53\end{array}$ & $\begin{array}{c}44 \leq \eta_{w h} \\
<53\end{array}$ & $\begin{array}{c}53 \leq \eta_{w h} \\
<61\end{array}$ & $\begin{array}{c}55 \leq \eta_{w h} \\
<72\end{array}$ & $\begin{array}{c}100 \leq \eta_{w h} \\
<130\end{array}$ & $\begin{array}{l}115 \leq \eta_{w h} \\
<150\end{array}$ & $\begin{array}{c}123 \leq \eta_{w h} \\
<160\end{array}$ & $\begin{array}{c}131 \leq \eta_{w h} \\
<170\end{array}$ \\
\hline A & $\begin{array}{c}35 \leq \eta_{w h} \\
<44\end{array}$ & $\begin{array}{c}35 \leq \eta_{w h} \\
<44\end{array}$ & $\begin{array}{c}38 \leq \eta_{w h} \\
<53\end{array}$ & $\begin{array}{c}38 \leq \eta_{w h} \\
<55\end{array}$ & $\begin{array}{c}65 \leq \eta_{w h} \\
<100\end{array}$ & $\begin{array}{c}75 \leq \eta_{w h} \\
<115\end{array}$ & $\begin{array}{c}80 \leq \eta_{w h} \\
\quad<123\end{array}$ & $\begin{array}{c}85 \leq \eta_{w h} \\
<131\end{array}$ \\
\hline B & $\begin{array}{c}32 \leq \eta_{w h} \\
<35\end{array}$ & $\begin{array}{c}32 \leq \eta_{w h} \\
<35\end{array}$ & $\begin{array}{c}35 \leq \eta_{w h} \\
<38\end{array}$ & $\begin{array}{c}35 \leq \eta_{w h} \\
<38\end{array}$ & $\begin{array}{c}39 \leq \eta_{w h} \\
<65\end{array}$ & $\begin{array}{c}50 \leq \eta_{w h} \\
<75\end{array}$ & $\begin{array}{c}55 \leq \eta_{w h} \\
<80\end{array}$ & $\begin{array}{c}60 \leq \eta_{w h} \\
<85\end{array}$ \\
\hline $\mathrm{C}$ & $\begin{array}{c}29 \leq \eta_{w h} \\
\quad<32\end{array}$ & $\begin{array}{c}29 \leq \eta_{w h} \\
<32\end{array}$ & $\begin{array}{c}32 \leq \eta_{w h} \\
<35\end{array}$ & $\begin{array}{c}32 \leq \eta_{w h} \\
<35\end{array}$ & $\begin{array}{c}36 \leq \eta_{w h} \\
<39\end{array}$ & $\begin{array}{c}37 \leq \eta_{w h} \\
<50\end{array}$ & $\begin{array}{c}38 \leq \eta_{w h} \\
<55\end{array}$ & $\begin{array}{c}40 \leq \eta_{w h} \\
<60\end{array}$ \\
\hline $\mathrm{D}$ & $\begin{array}{c}26 \leq \eta_{w h} \\
<29\end{array}$ & $\begin{array}{c}26 \leq \eta_{w h} \\
<29\end{array}$ & $\begin{array}{c}29 \leq \eta_{w h} \\
<32\end{array}$ & $\begin{array}{c}29 \leq \eta_{w h} \\
<32\end{array}$ & $\begin{array}{c}33 \leq \eta_{w h} \\
<36\end{array}$ & $\begin{array}{c}34 \leq \eta_{w h} \\
<37\end{array}$ & $\begin{array}{c}35 \leq \eta_{w h} \\
<38\end{array}$ & $\begin{array}{c}36 \leq \eta_{w h} \\
<40\end{array}$ \\
\hline $\mathrm{E}$ & $\begin{array}{c}22 \leq \eta_{w h} \\
<26\end{array}$ & $\begin{array}{c}23 \leq \eta_{w h} \\
<26\end{array}$ & $\begin{array}{c}26 \leq \eta_{w h} \\
<29\end{array}$ & $\begin{array}{c}26 \leq \eta_{w h} \\
<29\end{array}$ & $\begin{array}{c}30 \leq \eta_{w h} \\
<33\end{array}$ & $\begin{array}{c}30 \leq \eta_{w h} \\
<34\end{array}$ & $\begin{array}{c}30 \leq \eta_{w h} \\
<35\end{array}$ & $\begin{array}{c}32 \leq \eta_{w h} \\
<36\end{array}$ \\
\hline $\mathrm{F}$ & $\begin{array}{c}19 \leq \eta_{w h} \\
<22\end{array}$ & $\begin{array}{c}20 \leq \eta_{w h} \\
<23\end{array}$ & $\begin{array}{c}23 \leq \eta_{w h} \\
<26\end{array}$ & $\begin{array}{c}23 \leq \eta_{w h} \\
<26\end{array}$ & $\begin{array}{c}27 \leq \eta_{w h} \\
<30\end{array}$ & $\begin{array}{c}27 \leq \eta_{w h} \\
<30\end{array}$ & $\begin{array}{c}27 \leq \eta_{w h} \\
<30\end{array}$ & $\begin{array}{c}28 \leq \eta_{w h} \\
<32\end{array}$ \\
\hline G & $\eta_{w h}<19$ & $\eta_{w h}<20$ & $\eta_{w h}<23$ & $\eta_{w h}<23$ & $\eta_{w h}<27$ & $\eta_{w h}<27$ & $\eta_{w h}<27$ & $\eta_{w h}<28$ \\
\hline
\end{tabular}




\section{What are the requirements for ecodesign?}

From 26 September 2015 heat pumps and electric boilers must meet minimum requirements for seasonal space heating energy efficiency. Units for combined space and water heating must also meet minimum requirements for water heating efficiency and heat pumps must meet maximum sound power levels. The requirements will be tightened from 26 September 2017.

\section{Requirements for seasonal space heating energy efficiency}

Heat pumps and electric boilers for space heating and for combined space and water heating with a rated output $\leq 400 \mathrm{~kW}$ must meet the requirements for seasonal space heating energy efficiency listed in Table 5.

\section{Requirements for water heating efficiency}

The minimum requirements for water heating energy efficiency for heat pumps and electric boilers for combined space and water heating will be introduced in two stages. Table 6 and 7 show the minimum requirements from 26 September 2015 and the tightened requirements from 26 September 2017.
Table 5: Requirements for seasonal space heating energy efficiency. The seasonal space heating energy efficiency must meet the minimum requirements listed in the table

\begin{tabular}{|c|c|c|}
\hline Type & $\begin{array}{c}\text { Requirements for } \\
\text { seasonal space heating } \\
\text { energy efficiency } \\
26 \text { September } 2015\end{array}$ & $\begin{array}{c}\text { Requirements for } \\
\text { seasonal space heating } \\
\text { energy efficiency } \\
26 \text { September } 2017\end{array}$ \\
\hline Electric boilers & $\geq 30 \%$ & $\geq 36 \%$ \\
\hline $\begin{array}{l}\text { Heat pumps (except } \\
\text { low temperature heat } \\
\text { pumps) }\end{array}$ & $\geq 100 \%$ & $\geq 110 \%$ \\
\hline $\begin{array}{l}\text { Low temperature } \\
\text { heat pumps }\end{array}$ & $\geq 115 \%$ & $\geq 125 \%$ \\
\hline
\end{tabular}

Table 6: Requirements for water heating energy efficiency from 26 September 2015. The water heating energy efficiency must meet the minimum requirements listed in the table

\begin{tabular}{|c|c|c|c|c|c|c|c|c|c|c|}
\hline Declared loud profile & $3 \mathrm{xs}$ & $\mathrm{xxs}$ & xs & $s$ & M & t & $\mathrm{xt}$ & $\mathrm{xxt}$ & $3 \mathrm{XL}$ & $4 \times \mathrm{XI}$ \\
\hline $\begin{array}{l}\text { Water hesting } \\
\text { energy efficiency }\end{array}$ & $22 \%$ & 238 & $26 \%$ & $26 \%$ & $30 \%$ & $30 \%$ & $30 \%$ & $32 \%$ & $32 \%$ & $32 \%$ \\
\hline
\end{tabular}

Table 7: Requirements for water heating energy efficiency from 26 September 2017. The water heating energy efficiency must meet the minimum requirements listed in the table

\begin{tabular}{l|c|c|c|c|c|c|c|c|c|c}
\hline Declared load profile & $3 \mathrm{XS}$ & $\mathrm{xxs}$ & $\mathrm{Xs}$ & $\mathrm{S}$ & $\mathrm{M}$ & $\mathrm{L}$ & $\mathrm{XL}$ & $\mathrm{XXL}$ & $3 \mathrm{XI}$ & $4 \mathrm{XI}$ \\
\hline $\begin{array}{l}\text { Water heating } \\
\text { energy efficiency }\end{array}$ & $32 \%$ & $32 \%$ & $32 \%$ & $32 \%$ & $36 \%$ & $37 \%$ & $38 \%$ & $60 \%$ & $64 \%$ & $64 \%$ \\
\hline
\end{tabular}




\section{Requirements for sound power level}

From 26 September 2015 heat pumps must meet certain requirements for sound. The sound power level for heat pumps must not exceed the values in Table 8.

\section{Miscellaneous}

Methods for measurement and calculation of different parameters are found in annex III of the
Ecodesign Regulation 813/2013. The measurement and calculation methods are identical to the ones used for energy labelling found in annex VII of Energy Labelling Regulation 811/2013. Harmonised methods will be published in the second half of 2015 at the earliest. Until then, measurements and calculations should be performed according to transitional methods published by the Commission.
In addition, a heat generator designed for a supply system and a heater housing to be equipped with such a heat generator must be tested with an appropriate heater housing and heat generator, respectively. This is relevant, for example, to the indoor and outdoor units of air-to-water heat pumps, where the outdoor unit is equivalent to the heat generator.

Table 8: Maximum permissible sound power level for heat pumps from 26 September 2015

\begin{tabular}{c|c|c|c|c|c|c|c}
\hline \multicolumn{2}{c|}{ Rated heat output $\leq 6 \mathrm{~kW}$} & \multicolumn{2}{|c|}{$\begin{array}{c}\text { Rated heat output }>6 \mathrm{~kW} \text { and } \\
\leq 12 \mathrm{~kW}\end{array}$} & $\begin{array}{c}\text { Rated heat output }>12 \mathrm{~kW} \text { and } \\
\leq 30 \mathrm{~kW}\end{array}$ & \multicolumn{2}{|c|}{$\begin{array}{c}\text { Rated heat output }>30 \mathrm{~kW} \\
\text { and } \leq 70 \mathrm{~kW}\end{array}$} \\
\hline $\begin{array}{c}\text { Sound power } \\
\text { level }\left(L_{W A}\right), \\
\text { indoors }\end{array}$ & $\begin{array}{c}\text { Sound } \\
\text { power level } \\
\left(L_{W A}\right), \\
\text { outdoors }\end{array}$ & $\begin{array}{c}\text { Sound } \\
\text { power level } \\
\left(L_{W A}\right), \\
\text { indoors }\end{array}$ & $\begin{array}{c}\text { Sound } \\
\text { power level } \\
\left(L_{W A}\right), \\
\text { outdoors }\end{array}$ & $\begin{array}{c}\text { Sound } \\
\text { power level } \\
\left(L_{W A}\right), \\
\text { indoors }\end{array}$ & $\begin{array}{c}\text { Sound } \\
\text { power level } \\
\left(L_{W A}\right), \\
\text { outdoors }\end{array}$ & $\begin{array}{c}\text { Sound } \\
\text { power level } \\
\left(L_{W A}\right), \\
\text { indoors }\end{array}$ & $\begin{array}{c}\text { Sound } \\
\text { power level } \\
\left(L_{W A}\right), \\
\text { outdoors }\end{array}$ \\
\hline $60 \mathrm{~dB}$ & $65 \mathrm{~dB}$ & $65 \mathrm{~dB}$ & $70 \mathrm{~dB}$ & $70 \mathrm{~dB}$ & $78 \mathrm{~dB}$ & $80 \mathrm{~dB}$ & $88 \mathrm{~dB}$ \\
\hline
\end{tabular}




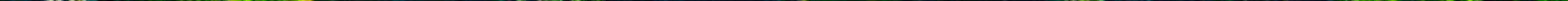




\section{What are the requirements for information and documentation?}

\section{Energy labelling}

\section{Energy label and product fiche}

All heat pumps and electric boilers for space heating or for combined space and water heating placed on the market from 26 September 2015 must be provided with a printed energy label and product fiche. A product fiche may include several models of heat pumps and electric boilers for space heating from the same supplier. See the guidelines for product fiches in Regulation on Energy Labelling, Annex IV.

Furthermore, electronic versions of the energy label and the product fiche must be made available to dealers for products placed on the market with a new model identifier. The layout of the electronic energy label must be identical with the printed label and the electronic versions of the label and the fiche must include the same information as the printed versions.

\section{Information in technical promotion material and in advertisements}

Relevant technical promotion material and advertisements for heat pumps and electric boilers shall include information on the energy class of the units. Further information is available in Regulation 811/2013/EU, Article 3 and 4.

\section{Labelling on the internet}

The electronic energy label and product fiche must be shown on the display in proximity to the price when heat pumps and electric boilers are offered for sale or hire through the internet. The label and the product fiche may be shown using a "nested display".

\section{Ecodesign}

\section{CE marking and EC declaration of conformity}

Heat pumps and electric boilers covered by the ecodesign requirements must be CE marked when they are placed on the market in the EEA countries.

\section{Furthermore, an EC declaration} of conformity must be available from which is must appear that the product complies with the requirements of the regulation. Consequently, the reference number of the Ecodesign Regulation EU No 813/2013 must be mentioned in the declaration of conformity.

You can find the requirements for the contents of an EC declaration of conformity in the Ecodesign Directive 2009/125/EC Annex VI.

\section{Ecodesign and energy labelling}

\section{Technical documentation}

The supplier is responsible for making sure that there is technical documentation for the heat pump or electric boiler when it is placed on the EEA market. The technical documentation must show that the heat pump or electric boiler is constructed in conformity with the ecodesign requirements and that the energy labelling of the heat pump or electric boiler is correct. The technical documentation must be compiled by the manufacturer.

For all heat pumps and electric boilers, you can see the requirements for technical documentation and information to be made available on the 
manufacturer's website in

Regulation 813/2013/EU Annex II, point 5 and in regulation 811/2013/

EU Annex V.

The market surveillance authorities of EEA countries may request the technical documentation, and you must provide it within a maximum of ten days after receiving the request.

The documentation relating to ecodesign requirements must be stored for a period of ten years after the last model of that product has been manufactured. In the case of energy labelling requirements, the documentation must be stored for five years.

\section{Measurement and calculation methods}

Reliable, accurate and reproducible measurement methods based on generally accepted measurement techniques must be used. $A$ reproducible measurement method means that the measurements can be repeated with the same result.

Measurements must always be carried out in accordance with the Regulations. 


\section{Where can I find information?}

The webpages of the national market surveillance authorities and the Commission (https://ec.europa. eu/energy/en/topics/energyefficient-products/heaters)

\section{Legislation \\ COMMISSION REGULATION} (EU) No 813/2013 of 2 August 2013 implementing Directive 2009/125/EC of the European Parliament and of the Council with regard to ecodesign requirements for space heaters and combination heaters.

DIRECTIVE 2009/125/EC OF THE EUROPEAN PARLIAMENT AND OF THE COUNCIL of 21 October 2009 establishing a framework for the setting of ecodesign requirements for energy-related products (recast).

\section{COMMISSION DELEGATED} REGULATION (EU) No $811 / 2013$ of 18 February 2013 supplementing Directive 2010/30/EU of the European

contain more information about policies, new regulatory requirements, guidance, contact information, and links to relevant legislation.

Parliament and of the Council with regard to the energy labelling of space heaters, combination heaters, packages of space heater, temperature control and solar device and packages of combination heater, temperature control and solar devices.

\section{DIRECTIVE 2010/30/EU OF THE EUROPEAN PARLIAMENT AND OF} THE COUNCIL of 19 May 2010 on the indication by labelling and standard product information of the consumption of energy and other resources by energy-related products (recast).

\section{COMMISSION DELEGATED} REGULATION (EU) No518/2014 of 5 March 2014 amending Commission Delegated Regulations (EU) No 1059/2010, (EU) No 1060/2010,
(EU) No 1061/2010, (EU) No 1062/2010, (EU) No 626/2011, (EU) No 392/2012, (EU) No $874 / 2012$, (EU) No 665/2013, (EU) No $811 / 2013$ and (EU) No $812 / 2013$ with regard to labelling of energy-related products on the internet.

\section{Where can I find help and guidance?}

You can get help to understand the requirements and answers to your questions by contacting your national market surveillance authority for ecodesign and energy labelling. 



\section{norden}

Nordic Council of Ministers

Ved Stranden 18

DK-1061 Copenhagen K

www.norden.org

ANP 2015:784

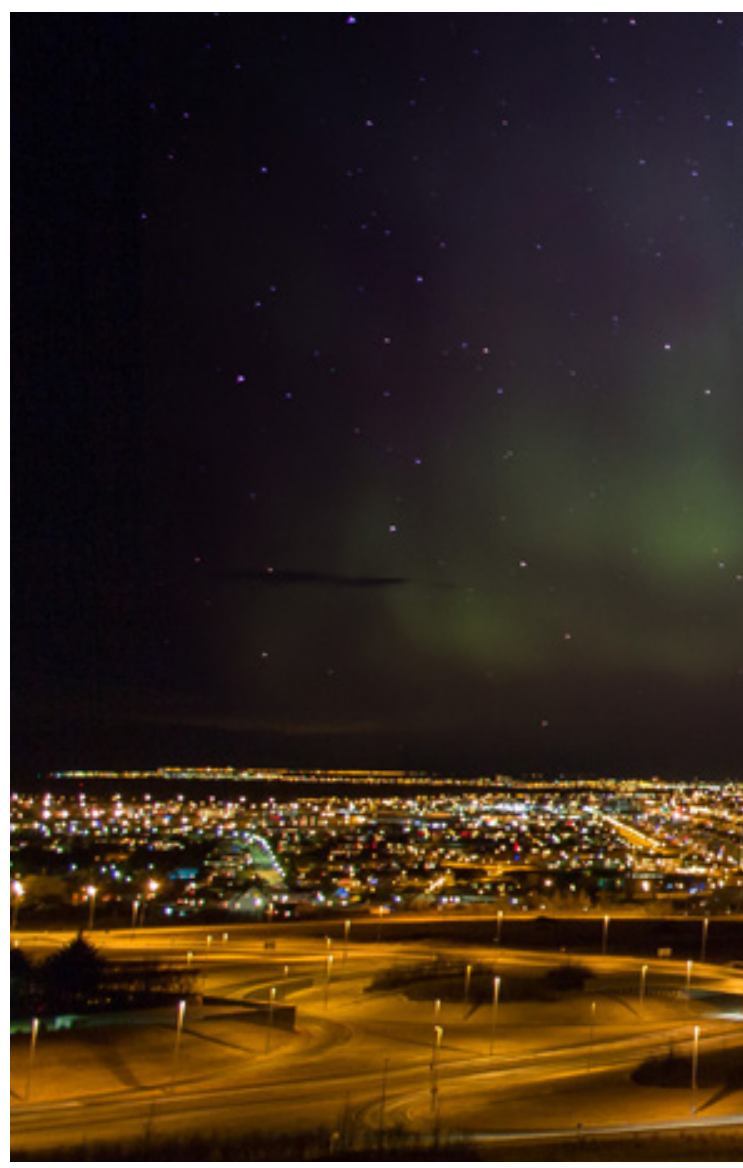

ISBN 978-92-893-4372-5 (PRINT)

ISBN 978-92-893-4373-2 (PDF) 